mag. Peter

Mlakar

\section{IZBOLJŠEVANJE POSLOVANJA V IZOBRAŽEVALNIH USTANOVAH}

$\mathbf{N}$ braževalne organizacije, ki se delno ali zmeraj bolj financirajo s prodajo izobraževalnih storitev. Zaradi tega je treba uvajati novosti na področju poslovnih procesov, storitev, organizacijske ureditve, marketin$\mathrm{ga}$, informacijske podpore poslovanju in tudi na področju odločanja o razvoju zaposlenih, motiviranja ljudi in navsezadnje pri nagrajevanju ljudi. V takšnih razmerah smo zaradi tesne povezanosti z evropskim gospodarstvom tudi v Sloveniji zelo odvisni

Najprej je treba doseči spremembe pri ljudeh. od dogajanja v Evropi. Zaradi obstoja in razvoja se moramo čim hitreje prilagoditi zahtevnim razmeram poslovanja $v$ turbulentnih razmerah. Največje spremembe so potrebne v miselnosti, torej »v glavah ljudi« (vodij, njihovih najožjih sodelavcev in zaposlenih, ki jih le-ti vodijo). Proces uspešnega obvladovanja sprememb sestavljajo tri stopnje. Zelo pomembno je, da se začne mišljenje spreminjati najprej na vseh ravneh vodenja in tudi med strokovnjaki izobraževalnih organizacij.

\section{ANALIZA POSLOVANJA PODJETIA}

Razmišljanje managerjev in strokovnjakov je treba usmeriti $\mathrm{k}$ odjemalcem izobraževalnih storitev in temu primerno oblikovati vizijo, strategije in poslanstvo, na tej podlagi pa zasnovati ali posodobiti sisteme delovanja. In kdaj uporabiti te sisteme?

Premiki v sedanjosti in zamrznitev primernejših vrednot na višji ravni potrebujejo čas. Da bi ugotovili, kaj zaposleni menijo o prednostih in slabostih delovanja organizacije, in s tem preverili ustreznost diagnoz, postavljenih na ravni vrhnjega in srednjega managementa, je priporočljiva izvedba ankete o zadovoljstvu zaposlenih, ki lahko v nekoliko razširjeni obliki da pravo sliko o delovanju podjetja v širšem smislu (krepitev želene kulture).

Pri anketiranju zaposlenih:

- moramo definirati želene skupne vrednote zaposlenih;

- je treba ugotoviti razlike med prevladujoči$\mathrm{mi}$ in želenimi vrednotami zaposlenih $\mathrm{v}$ oddelkih in v podjetju kot celoti;

- moramo okrepiti področja, kjer bodo ugotovljena največja neskladja (konkretni ukrepi);

- je treba oceniti, koliko so zaposleni dejansko sprejeli cilje kakovosti poslovanja;

- je smiselno predlagati ukrepe za izboljšanje podpore ljudi pri poslovanju podjetja;

- je smiselno opredeliti kriterije, ki bodo na strateški, taktični in operativni ravni podlaga za povezovanje delovanja ljudi in ugo- 
tavljanje njihove uspešnosti dela pri doseganju ključnih poslovnih ciljev.

Zaposleni naj bi torej imeli tudi možnost izraziti svoje mnenje o pomembnih področjih poslovanja in se vključiti $\mathrm{v}$ proces $\gg$ odmrznitve « neustreznih navad, postavljanja ustreznih navad in krepitve želenih navad v podjetju (odmrznitev, premiki, zamrznitev ...). Opraviti je treba tudi nabor najvplivnejših vrednot - te naj bi ponazorile dejanski pomen nekaterih vrednot v podjetju. V tovrstnih projektih je smiselno najprej ugotoviti identiteto skupnega delovanja ljudi, nato pa predlagati ukrepe, ki bodo na posameznike in skupine zaposlenih vplivali kot krepitev podobnega (želenega) delovanja. Hkrati s tem skušamo vplivati na pozitiven, čustven odnos do obvladovanja sprememb in procesa izboljševanja kakovosti poslovanja (pozitivne izkušnje podjetij, ki so uvedla programe izboljšav na podlagi poslovne odličnosti). Zaradi močnega vpliva procesov učenja na krepitev želene kulture podjetja je s sprotnim obveščanjem in seznanjanjem zaposlenih smiselno doseči njihovo neposredno vpletenost in preprečiti strah pred spremembami, ki jih prinaša sodobno poslovanje. S takšno krepitvijo kulture bomo ustvarili podlago, ki bo zaposlenim omogočala interakcijo in nadaljnje skupno delovanje $\mathrm{v}$ pogledu povezovanja podjetniških in osebnih ciljev.

Tudi kultura skupnega delovanja lahko zelo vpliva na učinkovitost in uspešnost poslovanja. Pri tem imajo odločilno vlogo vedenje in odločitve zaposlenih - predvsem vodij in strokovnih delavcev. V sodobnih razmerah poslovanja so oči uprte v:

- učinkovito vodenje,

- usmerjenost k tržišču in strankam,

- iskanje novih tržnih priložnosti,

- pooblaščanje in napredek zaposlenih,

- usmerjenost $\mathrm{k}$ procesom.
Sicer pa so po opravljenih raziskavah (Price Waterhouse, 1997) v ospredju voditeljstvo, vključenost zaposlenih in informiranost. To poudarja 59 odstotkov od 400 mednarodnih korporacij, 18 odstotkov daje poudarek delu z ljudmi, sledijo pa usmeritve $\mathrm{k}$ programu, obvladovanju nasprotij in spodbujanju ljudi z nagrajevanjem za uspehe. Uradno sprejeta kultura (to so vrednote in prepričanja vrhnjega managementa, izražena $v$ strateških načrtih) je pogosto drugačna od dejanske kulture med zaposlenimi. Vemo, da lahko $\mathrm{v}$ podjetju obstaja tudi vrsta »subkultur«, ki se prekrivajo ali se med seboj celo izključujejo. Zato je smiselno $z$ inte-
Oblikovanje kriterijev za ugotavljanje uspešnosti naj temelji na dejan- skih potrebah, ne zolj na ocenah vodstva.

gracijo dejanske in želene kulture sčasoma doseči:

- zavezovanje in motiviranje posameznikov ter skupin,

- izboljševanje koordinacije in nadzora,

- zmanjševanje možnosti za razdiralna nasprotja,

- opogumljanje zaposlenih za samozaupanje in uspeh,

- omogočanje tekmovalne prednosti.

Med najpomembnejšimi dosežki krepitve želene kulture bi bila lahko ohranitev stabilne tekmovalne prednosti (SCA = »sustainable competitive advantage «), ki je pravzaprav stalna postavka konkurenčne kakovosti, ki je konkurenti ne morejo doseči. SCA ni možno pridobiti le z ustreznimi poslovnimi odločitvami, ampak tudi s sistemom prepričanj, vrednot in oblikovanjem zmagovitega vedenja. To kasneje podpremo s kriteriji za ugotavljanje uspešnosti na ravni celotne organizacije, posameznih organizacijskih enot, skupin, projektov in na osebni ravni. 
Model za krepitev želene organizacijske kulture »Harmony«

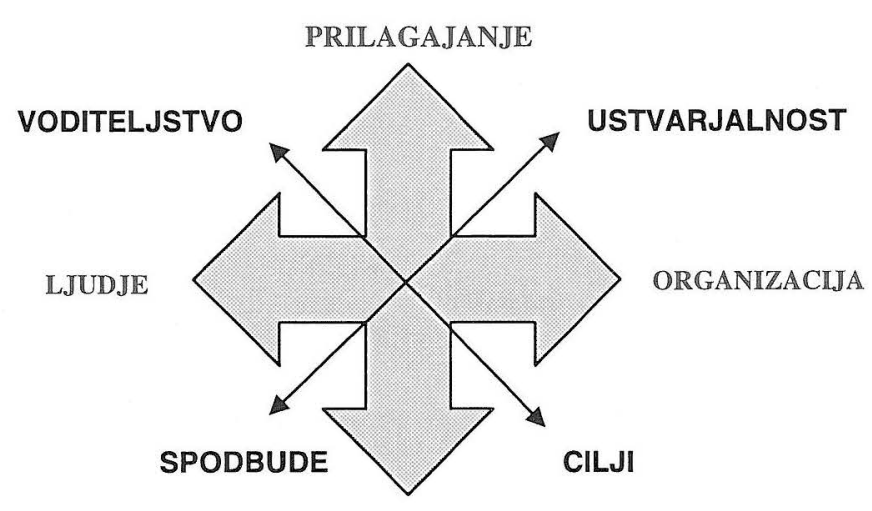

NADZOR

Shika l: Osem vidikov ugotavljanja organizacijske kulture podjetja (PQM)

Vprašalnik modela $\gg$ Harmony $\ll$ za ANKETIRANJE ZADOVOLJSTVA ZAPOSLENIH in ugotavljanje uravnoteženosti poslovanja na 18 naštetih področ̉ih vsebuje vprašanja o dejanski in želeni kulturi podjetja. Vprašanja so zastavljena tako, da sta iz odgovorov razvidna pristop (nacini in metode zasnove) in razširjenost (uporaba $v$ celotnem podjetju in poznavanje) na naslednjh področjin:

- vizija, poslanstvo,

- strategija, letni poslovni načrt,

- splośno mnenje o podjetju,

- kakovost procesov, izdelkov, povezav,

- organizacija poslovanja,

- mnenje o naravi dela,

- nagrajevanje in priznanja,

- vodstveni stil, lastnosti vodij,

- timsko in projektno delo,

- zagnano izvajanje,

- pooblaščanje in sodelovanje zaposlenih,

- znanje, razvoj in usposabljanje zaposlenih,

- lastnosti zaposlenin,

- vrednote, medsebojni odnosi,

- informiranost in komuniciranje,

- spodbudni motivi za uspešno delo,

- ovire za uspešno delo,

- normalna in razdiralna nasprotja.

\section{NOVI TIP MANAGEMENTA}

Obdobje globalizacije ponuja nove priložnosti. Praksa managementa se mora spremeniti. Odjemalci iščejo najboljšo vrednost (povezano s kakovostjo). Ne zanimajo jih makroekonomski učinki njihove odločitve o nakupu storitve, čeprav v končni fazi seštevek individualnih odločitev vpliva na to. Vsi se ne moremo spremeniti in postati boljši čez noč. Vendar lahko začnemo ta proces, ki so ga v razvitih državah začeli že nekaj let pred nami. Vsaka organizacija, ki samostojno sprejema odločitve, se lahko korenito izboljša. TQM kot pogosto uporabljen pojem pravzaprav opisuje tip h kakovosti usmerjenega managementa in pokriva veliko managerskih tehnik.

Program TQM mora obsegati štiri kriterije, če hoče biti uspešen:

- ves čas mora temeljiti na usmeritvi h kakovosti pri vseh aktivnostih - v vsakem procesu in pri vsakem delu;

- biti mora humanistično naravnan, v medčloveške odnose pa mora prinesti kakovost (v vodenje, motiviranje in vključevanje ljudi);

- temeljiti mora na decentralizaciji, ki zagotavlja izboljšave na vseh ravneh, še posebej izpostavljenih, tako da realnost predstavljata navdušenje in skupen namen, ne slogani;

- TQM mora biti uporabljen »holistično« tako da principi politike in postopki dosežejo vsak kotiček organizacije.

Pristop TQM mora oblikovati vse dele managerskega sistema, struktur in stila - ne le nekatere. Vsega ni treba narediti hkrati. Ta pristop lahko deluje uspešno v katerikoli državi, katerikoli organizaciji ne glede na velikost, panogo ali tržno nišo. Da bi bil program TQM uspešen, bi moral sistem kakovosti temeljiti na petih stebrih TQM, ki bi zagotavljali trdno podlago sistema. Creech meni, da je za uspešno obvladovanje pomembnih vseh pet stebrov. Izdelki (proizvodi in storitve) so osrednja točka podjetniškega cilja in uspeha. 


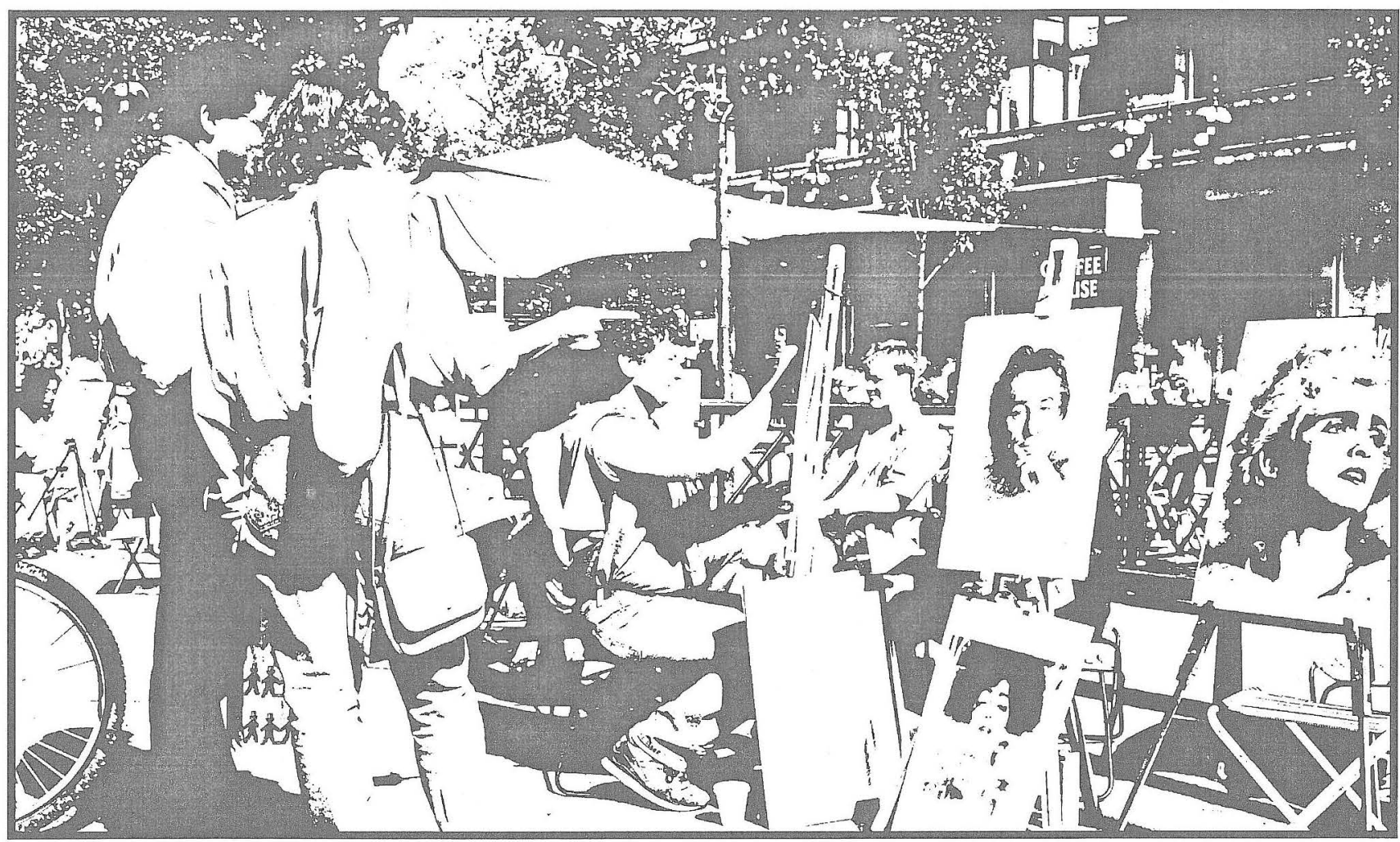

Kakovost izdelkov (storitev) ni mogoče doseči brez kakovosti procesov, kakovosti procesov pa ni mogoče doseči brez prave organiziranosti. Organiziranost je nepomembna, če je ne podpira primerno vodenje. Trden sistem odgovornosti (od spodaj navzgor) je podpirajoči steber drugih štirih stebrov. Vsi so med seboj tesno povezani in če je slaboten eden, so slabotni vsi.

Creech je pri praktičnem delu ugotovil, da obstajajo štiri skupine (načini) odzivanja managerjev na TQM:

- niso pokazali zanimanja (ne vidijo potrebe - se motijo);

- so pokazali interes, vendar so zmedeni (ne vedo, kako začeti in stvari uporabiti v praksi);

- so le delno uporabili principe TQM v posameznih delih podjetja;

- (popolnoma) razumejo principe TQM in se

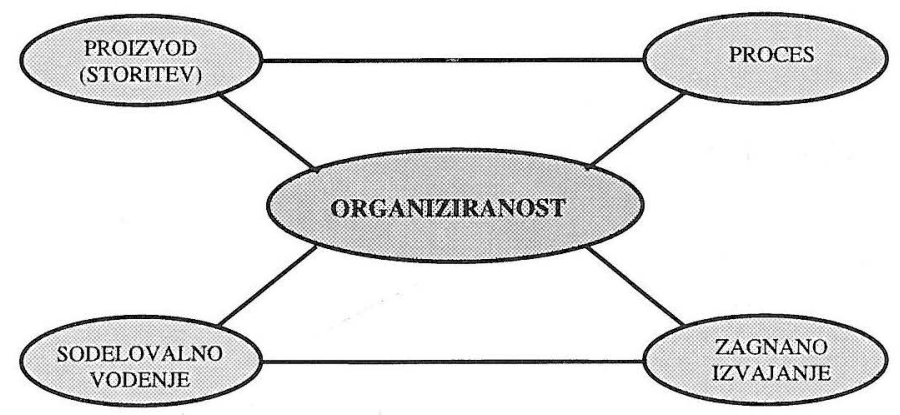

Slika 2: Pef stebrov TQM (Creech, B., 1994)

zavedajo, da mora uporaba teh principov vključiti celoten managementski sistem, ne samo delov; čeprav so uspešni, so se pripravljeni učiti od drugih in tako doseči še več uspeha; ključna lastnost za njihovo uspešnost je inovativnost; ta skupina je v manjšini.

Dolgoletna organiziranost po poslovnih funkcijah z navpično centralizirano strukturo, ki se je razvila $v$ novejšo matrično strukturo ( $v$ šest- 
desetih in sedemdesetih letih), se je v sedanjih razmerah globalizacije izkazala za neustrezno. Centralizem negativno vpliva na sistem, strukturo in stil (psiha in duh vseh zaposlenih). Naj- pomembnejši sistem je »človeški sistem«, ki ga ima vsaka organizacija oziroma podjetje. Ta podpira (ali pa ne) vse druge sisteme. Organiziranost je osrednji steber od petih stebrov TQM. Je ogrodje, na katerem temelji učinkovitost popolnega managerskega sistema. V času globalizacije so nujne organizacijske spremembe in najučinkovitejša pot za organizacijske spremembe je timsko delo (stalni timi v organizacijski strukturi).

\section{MOBILIZIRANJE LJUDI}

Ena od ključnih vlog voditeljev je mobiliziranje ljudi v celotni organizaciji, da bi spremenili delo. Voditelji morajo najprej odpraviti dolgoletni vzorec, ko so vsi pričakovali od njih ključne rešitve. Vprašajmo se, kako uresničujemo načelo $5 \mathrm{~K}$ ? Ali smo ljudem povedali, čemu izvajamo naše naloge? Ali vemo, da imamo na vprašalnice: kaj, kdo, kje, kdaj največ odgovorov mi, na vprašalnico kako pa jih pričakujemo od naših sodelavk in sodelavcev? Ti so namreč strokovnjaki na svojem področju, zaradi tega tudi opravljajo delo na zahtevnih delovnih področjih. Pritegnimo tudi njih. Možnosti za spremembe so namreč v kolektivni sposobnosti zaposlenih na vseh ravneh, ki morajo uporabiti drug drugega kot vir (pomoč) pri reševanju skupnih problemov. Voditelji morajo oblikovati nove vloge, nove pristope $\mathrm{k}$ delu, nove vrednote, nove navade in nove običaje pri delu. Mnogo zaposlenih še zmeraj pričakuje, da bodo najvišji vodje probleme prevzeli na svoja ramena.

Vsakdo ima svoj pogled na zadeve, ki izhaja iz njegovega razumevanja stvari. Ljudje prepogosto pričakujejo, da bodo vodje opravili to, za kar so sami odgovorni. Raje so pasivni, ker odločilne akcije izvajajo tako imenovani reševalci problemov - vodje. To ljudi ščiti pred odgovornostjo, bolečino in potrebo po spremembi. Dati ljudem več odgovornosti ni lahka naloga. Mnogo zaposlenih na najnižjih ravneh si raje pusti povedati, kaj morajo narediti, mnogo vodij pa si podrejenost razlaga kot »stroj za nadziranje «. Dovoliti ljudem, da prevzamejo pobudo in da rešujejo probleme, pomeni, da se mora management naučiti podpirati namesto samo nadzirati.

Zaposleni naj bi se naučili sprejemati odgovornost ... Ključ do tega je, da se v podjetju uvede dinamična delitev dela, zaposleni pa na tej podlagi sami odkrijejo probleme in njihovo rešitev. Treba je tudi spodbujati samospoštovanje, ki prihaja iz uspeha, izkušenj in organizacijskega okolja. Tudi ko pride do napak, je treba ponovno ustvariti samozaupanje. Priporočljivo je, da usmeritev $\mathrm{k}$ funkcijam in inputom $v$ podjetjih spremenimo $v$ orientacijo $\mathrm{k}$ procesom in outputom. Prave učinke, ki jih vidi odjemalec, ugotovimo, kadar so na voljo oziroma kadar jih ugotovimo in ocenimo. Izboljšanje učinkov je možno s povečanjem skupne odgovornosti, ki se kaže v boljših povezavah med delnimi procesi, boljšem sporazumevanju in boljšem upravljanju procesov.

Kadar govorimo o obvladovanju sprememb in o preurejanju vloge vodenja, se nujno dotaknemo pooblaščanja zaposlenih in nasprotno - sistemi vodenja in nagrajevanja naj bi zagotavljali povečanje odgovornosti in s tem sodelovalnosti čim večjega števila zaposlenih. Preurejanje vloge vodenja je posledica zahteve po preureditvi organiziranosti (tradicionalni funkcijski pogled na organiziranost je smiselno $\mathrm{z}$ dopolnitvami preusmeriti $\mathrm{v}$ procesni pogled). Pooblaščanje zaposlenih je pravi odgovor na premajhno učinkovitost togih in razraščenih organizacijskih piramid, ki so nastale v obdobju, ko je bilo povpraševanje nad ponudbo. Podobni procesi potekajo tudi pri nas. Ali bomo lahko to dosegli brez preureditve vodenja in brez pooblaščanja zaposlenih? »Kako- 
vost so ljudje « je izjavil edini evropski »guru « kakovosti Klaus Moeller. Ali to velja v podjetjih s prevladujočimi hierarhičnimi odnosi med vpletenimi? Menim, da je treba najprej preveriti znanje tistih, ki najbolj vplivajo na nadaljevanje omenjenih procesov v podjetju - znanje srednjega in operativnega managementa in znanje strokovnjakov.

\section{POVEZOVANJE DINAMIČNE DELITVE DELA IN SISTEMIZACIJE DELA}

Na začetku prispevka je bilo omenjeno, da je spodbujanje ljudi z nagrajevanjem za uspehe izvedljivo le z integracijo dejanske in želene kulture podjetja. Sistemi motiviranja v slovenskih organizacijah morajo tako kot $\mathrm{v}$ mednarodnih korporacijah podpirati zavezovanje in motiviranje posameznikov ter skupin, izboljševanje koordinacije in nadzora, zmanjševanje možnosti za razdiralna nasprotja, opogumljanje zaposlenih za samozaupanje in uspeh, omogočanje tekmovalne prednosti.

Rekli bi lahko, da je pri tem veliko možnosti za napačno ravnanje. Zato se pred odločitvijo za posodobitev plačnega sistema opredelimo o posameznih metodah dela, ki bodo po uspešnem diagnosticranju pripravljene, preden bomo začeli projekt posodabljanja sistema nagrajevanja.
Drugič - zelo pomembna je tudi odločitev, da bomo organiziranost poslovanja, delitev dela in sistemizacijo dela dinamično povezali. Hkrati s tem v organiziranost poslovanja uvedemo sodobne principe izboljševanja kakovosti poslovanja.

Za izrabo ustvarjalnega potenciala zaposlenih, še posebej pri timskem načinu dela, je zelo pomembno upoštevanje vseh razsežnosti motiviranja. Morda dajemo premalo poudarka notranjim spodbudam, ki so kljub velikemu pomenu materialnih spodbud odločilne za uspeśno delo posameznikov in timov. V času, ko je na vseh področjih vse pomembnejša potreba po kakovosti izdelkov in storitev, je motiviranje zaposlenih s kakovostjo eden od vzvodov, ki bo krepil njihove notranje spodbude.

$\mathrm{V}$ večini slovenskih podjetij (kljub nekaterim izjemam) še ni opredeljene prave procesne organiziranosti (večinoma se nekoliko aktualizirana funkcijska organiziranost terminološko opredeljuje kot procesna organiziranost), vendar jo je možno $\mathrm{v}$ prehodnem obdobju krepiti z ustanavljanjem stalnih medfunkcijskih ali drugih timov. Ti imajo zelo jasno opredeljene strukturo, cilje, udeležence, naloge in sistem povezav s funkcijskimi organizacijskimi enotami. Tudi nagrajevanje članov teh timov je prilagojeno procesnim nalogam. Najpomembnejše predhodno dejanje pri tem je opredelitev managementa do ključnih poslovnih procesov $v$ pogledu verige $\gg$ notranji

Prvič - ponovimo že znano Adizesovo razdelitev nagrad na zunanje in notranje:

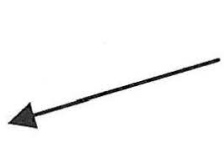

ZUNANJE

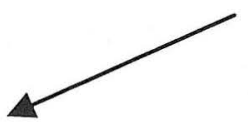

Denarne nagrade
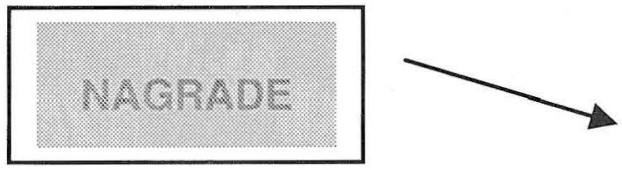

NOTRANJE

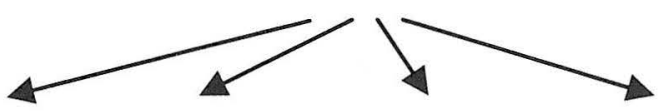

Moč Poslanstvo

(E) 
dobavitelj - odjemalec «. Utvara bi bila, če bi pričakovali, da bo procesna organiziranost $\mathrm{v}$ pravem pomenu začela delovati takoj, zaradi različnih vzrokov. Čeprav je pri tem lahko mnogo dilem, vsako odlašanje povečuje razliko med razvitostjo našega poslovanja nasproti najuspešnejšim. Vendar je treba omeniti tudi to, da je krepitev procesne organiziranosti v marsičem odvisna od dejavnosti organizacije in od organizacijske strukture, zato je v nekaterih organizacijah dinamično delitev dela možno izvesti na podlagi nalog. Vsekakor ni potrebe po odlašanju z uvajanjem nagrajevanja uspešnosti.

Povezovanje organiziranosti poslovanja, delitve dela in sistemizacije dela je možno učin-

Dinamična delitev dela pripomore $k$ izboljšanju kakovosti. kovito podpreti $\mathrm{z}$ računalniškim programom, ki zagotavlja, da so hiararhične povezave in procesne povezave aktualne in brez velike »papirnate vojne« pregledne ter znane vsem zaposlenim. To je tudi odlična priložnost za vključitev zaposlenih pri opredeljevanju (ne)potrebnih nalog, ki sestavljajo opis dela za posamezno delovno področje (po veljavni zakonodaji: delovno mesto).

Sodobni principi izboljševanja kakovosti poslovanja se kažejo v vsebini pravilnika o organizaciji poslovanja (praktični primer, ki vključuje načela sistemizacije dela):

- skupni principi izboljševanja kakovosti poslovanja,

- shema povezav organizacijskih področij,

- organizacijska zgradba (delitev dela),

- vloga vodij,

- vloga timskega dela pri vodenju (stalne in občasne koordinacije),

- projektno timsko delo,

- vključenost zaposlenih v timsko delo,

- razmejevanje pristojnosti,

- načela in cilji sistemizacije delovnih mest,
- oblikovanje delovnih mest in razporejanje delavcev,

- podatki in dokumentacija o delovnih mestih,

- seznam delovnih mest po organizacijskih enotah,

- urejanje poslovanja $\mathrm{z}$ organizacijskimi predpisi,

- principi nadaljnjega razvoja organizacije.

Tretjič - pri opredeljevanju koristnih in izločanju nekoristnih nalog je na podlagi vnaprej znane metode treba pritegniti vse zaposlene, vodje, strokovnjake in deloma tudi izvajalce, ki aktivno sodelujejo pri posameznih procesih.

Širina vključitve osebja je odvisna od ciljev urejanja nalog in ocene managementa, v kolikšnem obsegu je treba urejanje izvesti. Pravzaprav gre za prenavljanje delitve dela, ki je v marsikateri organizaciji zastarela in statična (opisi dela so zastareli, vsebujejo zastarele naloge). Ponekod opisi dela vsebujejo tudi aktivnosti in delovne operacije, ki ne spadajo v opise, ampak v navodila za delovno mesto (lokacija izvedbe delovnih operacij). Posodobitev delitve dela je torej odlična priložnost, da s sodelovanjem izvajalcev optimiramo mikroorganiziranost dela in izločimo naloge, ki nimajo dodane vrednosti oziroma so same sebi namen. Gre torej za optimiranje delovnih postopkov in vnovičen premislek o dodani vrednosti vseh nalog, ki jim hkrati s tem začenjamo opredeljevati tudi cilje. Odgovor je na dlani: kadar se sprašujemo zakaj, kdo, kaj, kje in kako v zvezi s posamezno nalogo, ugotovimo tudi prejemnika rezultata in cilj, ki naj bi ga dosegli $z$ izvedbo posamezne naloge.

\section{SISTEM ZA UGOTAVLJANIE USPEŠNOSTI DELA}

Plačevanje uspešnosti dela $v$ organizaciji je neposredno povezano z realnimi poslovnimi cilji, načrtovanimi na letni in mesečni ravni. 
Pri predpostavki, da so vnaprej določeni mesečni, četrtletni ali letni cilji, temelji plačevanje uspešnosti na uresničitvi postavljenih ciljev v posameznem obdobju. Sistem ocenjevanja uspešnosti dela je sestavljen iz:

- skupin uspešnosti organizacije kot celote, organizacijskih enot, projektov ali »ad hoc«;

- delovne uspešnosti posameznikov;

- nagrad in bonusov.

Že v uvodu smo omenili, da je nagrajevanje ljudi del motivacijskega sistema, s katerim želijo organizacije vplivati na delovanje zaposlenih pri doseganju poslovnih ciljev. Pri tem se nujno srečamo $s$ sistemom načrtovanja in $s$ sistemom motiviranja ljudi v širšem smislu.

\section{a) Sistem načrtovanja}

V obdobju, ko ponudba presega povpraševanje (odjemalci oziroma kupci so vir, ki ga primanjkuje), je treba vse podjetniške vire preusmeriti na odjemalce in veščine blizu odjemalca. Tudi z ugotavljanjem uspešnosti in njenim nagrajevanjem je smiselno podpreti tovrstne usmeritve. Pomemben je prehod od filozofije »iz izdelka« na filozofijo »v tržišče«. Hkrati gre za prehod od standardizacije $\mathrm{k}$ individualizaciji in tekmovanju s kakovostjo s stroškovno ter časovno učinkovitostjo. Maksimizacija dodane vrednosti je torej dosegljiva $\mathrm{z}$ maksimizacijo pozitivne kakovosti (prepoznavanje večje vrednosti za enak denar).

Pri povezovanju načrtovanja in določanja kri-

Že pred leti je Conti zapisal, da je kakovost ciljev vsaj tako pomembna kot kakovost izvedbe. Kakovost ciljev je torej nujna za kakovostno določanje kriterijev, kot podlage za merjenje naših dosežkov na skupni, oddelčni in osebni ravni. Brez tega ne more biti učinkovitega ugotavljanja uspešnosti in nagrajevanja ljudi za preseganje pričakovanih ciljev. terijev za ugotavljanje uspešnosti ne gre samo za izboljševanje rezultatov kakovosti, ampak tudi za izboljševanje ciljev kakovosti. Poglavitni cilj razširitve kakovosti na podsisteme kakovosti naj bi bili povečevanje zadovoljstva odjemalcev, zniževanje stroškov in povečevanje prilagodljivosti podjetja. Ljudi moramo motivirati za prave cilje. Načrtovanje poslovanja naj zajema vse dele sistema kakovosti poslovanja, katerih namen je povečati zadovoljstvo odjemalcev in povečati dobiček.

\section{b) Sistem merjenja učinkov}

Poleg tega pa moramo upoštevati tudi mnenje Kaplana in Nortona, ki zagovarjata uvajanje uravnoteženih kazalnikov za merjenje učinkov. Bistveno pri tem je, kako ustvarjamo in izboljšujemo dodano vrednost. Izhajajoč iz vizije, poslanstva in strategije, naj bi organizacije upoštevale štiri vidike:

- vidik kupcer (odjemalcev),

- finančni vidik,

- notranji in poslovni vidik (procesi),

- vidik inovacij in učenja.

Kaplan in Norton menita, da je za vsako področje mogoče in treba izdelati cilje, kazalnike in ukrepe. $\mathrm{Z}$ metodo prenašanja strategije podjetja med ljudi je mogoče doseči povezovanje dolgoročnih in kratkoročnih ciljev podjetja. Kadar na osnovi računalniško podprte dinamične delitve dela izdelamo takšen sistem kazalnikov, ki upošteva vse štiri stopnje Demingovega kroga PDCA (načrtuj, izdelaj, meri, ukrepaj), lahko povežemo delitev dela $\mathrm{s}$ cilji in $\mathrm{z}$ merjenjem učinkov. Managerji, ki imajo letne pogovore z zaposlenimi brez ustreznega sistema ciljev in kazalnikov, imajo vsekakor zelo zahtevno nalogo, ki jo je mogoče precej olajšati s povezovanjem dinamične delitve dela, na tej temelječimi cilji v skladu s krogom PDCA in s tem povezanimi kazalniki ter ukrepi za doseganje 


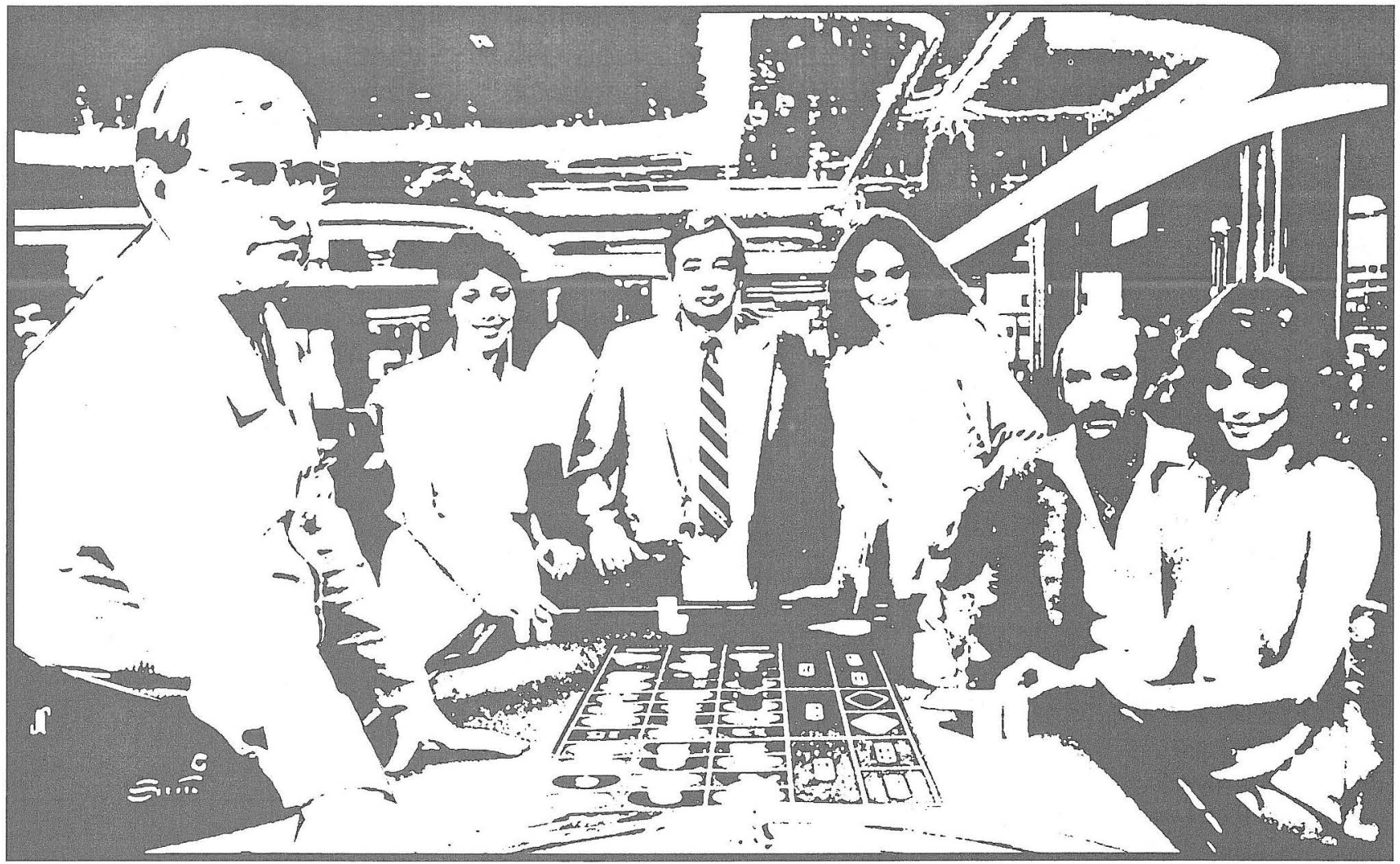

ciljev. To je tudi dovolj dobra podlaga za naslednji korak - ugotavljanje in vrednotenje različnih vrst uspešnosti.

Motiviranje zaposlenih je torej smiselno obravnavati v zvezi $\mathrm{z}$ delovanjem sistema kakovosti $\mathrm{v}$ podjetju, ki povezuje različne podsisteme (povezane $z$ izdelkom, okoljem, zaposlenimi, partnerji in upravnim aparatom). Gre za vidike motiviranja ljudi s perspektivo (rast podjetja in osebna rast), s prijetnim in ustvarjalno-inovativnim razpoloženjem pri delu, $\mathrm{z}$ razumljivim in spodbudnim sistemom plačevanja dela ter dosežkov in z mnogimi drugimi sestavinami, ki izhajajo iz kooperativnega (partnerskega) sodelovanja med organizacijo in ljudmi.

Procesno preurejanje vpliva tudi na (ne)koristnost dela. Ljudje so motivirani le, kadar opravljajo koristno delo (zase, za organizacijo ...). Vloge se zamenjajo - pooblastila preidejo na ljudi, s tem na njih preide tudi odgo- vornost za odločitve in vpliv na rezultate lastnega dela. Učinki dela se obravnavajo drugače. Namesto plačila za čas, ki ga ljudje »prebijejo v službi« (v funkcijski delitvi dela), je pri procesni delitvi dela v ospredju plačilo na podlagi ustvarjene vrednosti. Sodobni avtorji trdijo (Hammer, Champy), da so osnovne plače v podjetjih s preurejenimi procesi nizke, dodatne nagrade za velike dosežke pa se izplačujejo kot bonusi, ne kot povišanje plač. V preurejenih podjetjih je podlaga $\mathrm{za}$ nagrajevanje prispevek in učinek posameznika, ki se meri po ustvarjeni dodani vrednosti. Hammer in Champy navajata, da je bonus nagrada za ustrezno opravljeno delo, ne pa napredovanje na novi položaj. Jasno je torej treba razmejiti napredovanje in učinek. »Posameznik napreduje znotraj organizacije zaradi svojih sposobnosti, ne učinka, « menita. Napredovanje je sprememba, ne pa nagrada. 
Plačevanje po učinku in napredovanje po sposobnostih zagovarjajo tudi nekateri domači strokovnjaki s področja vrednotenja dela. Pri vrednotenju uspešnosti je možno izbirati med splošnimi, specifičnimi in drugimi kriteriji. Izbor je odvisen od predmeta poslovanja organizacije, od obdobja v življenjskem ciklu, od postavljenih ciljev in opredelitve kazalnikov. V praksi je možno precej rezultatov izmeriti, druge pa je možno oceniti. Bistveno je, da so kriteriji postavljeni vnaprej in da so namenjeni realnemu merjenju/ocenjevanju rezultatov.

\section{c) Sistem za ugotavljanje in vrednotenje uspešnosti}

Omenili smo že, da omogoča računalniško podprti sistem za ugotavljanje in vrednotenje uspešnosti ocenjevanje pričakovanega učinka, kadar so cilji načrtovani in s strateške ravni preneseni na osebne cilje. Ocenjevanje osebne uspešnosti na primer temelji na razlikah med pričakovanim učinkom (načrtovani cilji) in dejansko doseženimi rezultati.

Ocenjevanje različnih vrst uspešnosti poteka z ugotavljanjem odstopanja od ciljev na več področjih. Kriterije izberemo iz nabora kriterijev. Dosežen učinek je enak načrtovanemu pri oceni 3, ko je odstopanje od cilja ničodstotno. Računalniški program PQM-EFECT, ki podpira sistem ugotavljanja in vrednotenja delovne uspešnosti, omogoča hitro in učinkovito izračunavanje skupnega odstotka uspešnosti na več ravneh:

- za organizacijo kot celoto,

- za posamezne organizacijske enote,

- za skupine,

- za projekte,

- osebno uspešnost,

- nagrade (koristni predlogi, bonusi),

- inovacije,

- drugo.

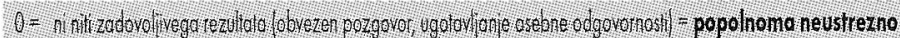

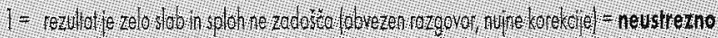

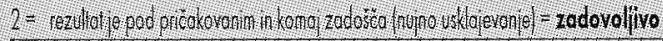

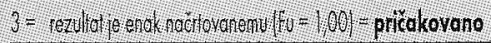

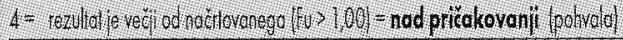

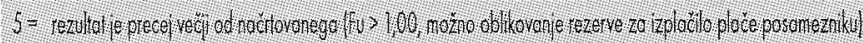

z zelo uspesino laghida zgled disigir

Poleg tega omogoča simuliranje ocenitve uspešnosti (razdeljevanje mase sredstev z upoštevanjem plač zaposlenih), akontiranje, obračunavanje in poračunavanje posameznih vrst uspešnosti. Evidence za posameznike, enote in organizacijo kot celoto so pomemben zbir podatkov, ki ga lahko uporabljamo pri kadrovski politiki organizacije, načrtovanju razvoja zaposlenih itd. Program PQMEFECT je obogaten tudi s kadrovskimi evidencami, kar omogoča hitro in enostavno spremljanje razvoja zaposlenih. Pravzaprav je bil namen snovanja tega programa podpirati partnerstvo med podjetjem in zaposlenimi in tako omogočiti učinkovito uporabo orodij, ki jih sicer v praksi uporablja že precej slovenskih organizacij (na primer letni pogovori $\mathrm{z}$ zaposlenimi ...). Sistem za ugotavljanje in vrednotenje uspešnosti je tisti vzvod, ki ga poleg drugih (tudi nedenarnih načinov motiviranja ljudi za doseganje podjetniških ciljev) slovenske organizacije vse pogosteje uvajajo.

\section{LITERATURA}

Adizes, I.: Životni ciklusi poduzeća, Prometej, Novi Sad, 1994.

Brajša, P.: Sedem skrivnosti uspešnega managementa, Gospodarski vestnik, Ljubljana, 1996 (zbirka Manager).

Conti, T.: Building Total Quality - A guide for management, Chapman \& Hall, London, 1993 (izvirnik Costriure La Qualita Totale, Milan, 1992).

Creech, B.: The Five Pillars of TQM - How to Make Total Quality Management Work for You, Truman Talley Books/Dutton, New York, 1994.

De Raad, G.: Celovito obvladovanje kakovosti, referat na Konferenci zmagovalcev, Ljubljana, december 1997.

Drucker, P. F.: Praksa rukovodženja, Privreda, Zagreb, 1961. 
Gilgeous, V.: Operations and the Management of Change, Pitman Publishing, London, 1997.

Hammer, M., Champy, J.: Preurejanje podjetja (Manifest revolucije o poslovanju), Gospodarski vestnik, Ljubljana, 1995.

Kaplan, R. S., Norton D. P.: The Balanced Scorecard, Translating Strategy into Action, Harvard Business School Press, Massachusetts, 1996.

Mlakar, P.: Možnosti inovativnega obvladovanja kakovosti poslovanja podjetja, magistrsko delo, Ekonomskoposlovna fakulteta, Maribor, 1997.

Mlakar, P.: Modra knjiga Plače v Sloveniji, poglavje: Pomen organizacije dela pri gradnji sistema plač, Moderna organizacija, Kranj, 1995 (založilo Društvo za vrednotenje dela).

Mlakar, P.: Upravljanje s človeškimi viri, Seminar at Center Parcs - Belgija, Svetovalec, Gospodarski vestnik, št. 3, Ljubljana, 1997.

Mlakar, P.: Delavnica za vrhnji mamagement storitvenega podjetja Ali smo res najboljši? (Radenci, oktober 1997).

Moeller, C.: Ko vodilni zapirajo vrata, Gospodarski vestnik, št. 36, Ljubljana, september 1996.

Mulej, M.: Plačevanje inovacij, Modra knjiga - Plače v Sloveniji, Moderna organizacija, Kranj, 1995.

Rus, M: Zapiski s predavanj, Price Waterhouse, Pariz, oktober 1993.

Rus: Korporativna kultura ... in kompleksne spremembe, Price Waterhouse (Moskva), Posvetovanje Društva za vrednotenje dela, organizacijski in kadrovski razvoj, Bled, 1998.

Soin, S. S.: Total Quality Control Essentials - Key elements, Methodologies and Managing for Success, McGraw-Hill, Inc., New York, 1992. 